\title{
INNOVATION AS A FACTOR OF THE LABOR RESOURCES OF RURAL AREAS RESERVE
}

\author{
*Iryna Honcharenko, Nataliya Shyshpanova \\ Mykolaiyv National Agrarian University, Ukraine \\ *Corresponding author's email: ihoncharenko305@gmail.com
}

\begin{abstract}
The article considers the prospects of innovative entrepreneurship in the preservation of labor resources and attracting young people to ensure sustainable development of rural areas.

Rural areas of Ukraine due to social, economic, cultural, demographic and environmental processes lose their attractiveness for the population, which is mainly employed in their own households, such work in most cases leads to the loss of skills, is inefficient, exhausting and does not provide the desired standard of living.According to the results of modelling, which is presented in the article, the biggest part of population over the next decade is likely to focus on areas of activity related to intellectual work that requires higher education. As the opportunity to realize such advantages in rural areas is extremely limited, while maintaining modern conditions, the tendency to reduce the human potential of rural areas will increase. Therefore, according to the experience of the most competitive regions of the world, it is important for Ukraine to form and develop entrepreneurial regional innovation systems, whose main features are mobility, the ability to quickly respond and adequately change external operating conditions. In such systems, new knowledge is transferred between research centers and business structures through both formal and informal channels, by involving scientists in the implementation of innovative projects. Nowadays, about $20 \%$ of students want to get a modern higher education and after graduation to work in rural communities as entrepreneurs, but the ambition is higher and the current stage of the development shall be a transformational transition of rural regions of Ukraine to the model of innovative economy.
\end{abstract}

Key words: rural areas, labor resources, innovation, entrepreneurship.

\section{Introduction}

Negative trends in social, economic, cultural, demographic and environmental processes exacerbate the differences between living standards and economic development of the rural and urban areas. A common feature of the rural areas was the deterioration of the environment due to excessive land use in agricultural production, intensification of subsoil development by quarrying and exacerbation of the problem of garbage management. Relatively stable rules, methods and technologies that have succeeded in the past are no longer adequate to the current conditions of the rural economic development. This requires finding solutions aimed at achieving long-term goals in conditions of uncertainty, unpredictability and instability of the market environment. Achieving the goals of sustainable development of rural settlements in Ukraine requires the involvement of young people the most productive, innovative and flexible members of society among the rural population. In the research, we tried to analyse the modern status of the innovation development of the rural areas of Ukraine, youth plans for the future and their connection to the rural areas and build a model for the forecast, which becomes one of the basis for the creation of the results of research.

\section{Materials and Methods}

According to Joseph Schumpeter, 'Innovation is the only function that is fundamental in history' (Schumpeter, 1939). Schumpeter argues that innovation is the basis of economic growth, insisting that entrepreneurship itself contributes to the development of economic history. He also stressed that entrepreneurship itself 'replaces today's Pareto optimum with tomorrow's new thing,' transforming business practices so that they benefit the environment and society.

In the Strategy of the sphere of innovation activity development for the period up to 2030 approved by the Cabinet of Ministers of Ukraine on July 10, 2019 (Verkhovna Rada of Ukraine, 2020a) it is stated that in Ukraine there is a gradual degradation of innovation potential. To remedy the situation, it is declared to promote the development of high-intensity activities, i.e. the transition from low-tech resource to high-tech innovation economy, the focus of the public policy on creating favorable conditions, especially for the development of intellectual products, including their commercialization in Ukraine and the rest of the world.

Accordingly, the strategic directions of the Ukrainian regions' development shall be the strengthening of the knowledge-intensive economic activities that form V-VII technological systems: the fifth - electronic, measuring, fiber-optic technology, software, telecommunications, robotics, information services; sixth -nanoenergy, molecular, cellular, nanotechnology, nanobiotechnology, nanobionics, microelectronic technologies, nanomaterials, etc.; seventh - instrumentation and robotics, biocomputer systems and biomedicine, communication of artificial and organic systems. Today, new business ideas are primarily generated in agglomerations and large cities, where new concepts of sustainable development are 
being implemented. Thus, the headquarters of the most companies in the information technology industry are located in the main IT centers of the country $-\mathrm{mm}$. Kyiv, Kharkiv, Lviv, Dnipro and Odesa (Verkhovna Rada of Ukraine, 2020b).

The relationship between innovative entrepreneurship and conservation of labor resources in rural areas, attracts increased attention in the context of finding solutions that can ensure the achievement of sustainable development goals. The research methodology is based on methods of analysis and synthesis, modeling, interpretation and relevant comparisons.

\section{Results and Discussion}

Consider the Global Innovation Index, jointly published by Cornell University, the European Institute of Business Administration and a specialized agency of the World Intellectual Property Organization in order to identify trends in the innovative development of Ukraine's economy. Recognizing that innovation is a key driver of economic development, GII conducts and publishes rankings and analyzes of the situation in 131 economies around the world. The index measures innovation based on criteria that include: institutions, human capital and research, infrastructure, loans, investments, connections, creation, absorption and dissemination of knowledge, results. The 2020 report identifies Switzerland as the most innovative country, followed by Sweden, the United States and the United Kingdom. Ukraine ranks $45^{\text {th }}$ in the Global Innovation Index 2020, entering the TOP-2 countries of the economic group with lower-middle income (Global Innovation Index 2020, 2020).

Ukraine, unfortunately, lags behind neighbouring countries in terms of innovation, ranking 30th among 39 European countries (Global Innovation Index 2020 Ukraine, 2020).

The main indicators of the innovation potential of the regions correspond to the trends shown by Ukraine's rating according to the global innovation index. Due to the fact that individuals form the innovative potential of the region, we see a tendency to reduce the number of students in graduate school and doctoral studies, training of highly qualified researchers, for example, only in the Mykolaiv region during the last three years decreased by 61 people (Main department of statistics in the Mykolaiyv area, 2020), Table. 1

The high need of the economy for highly competitive scientific and technical developments is not provided with financial resources, in 2016-2019 there was a significant reduction in the cost connected with research and development in the region from all sources, Figure 1.

The lack of funding has a negative impact on the creation of intellectual property. According to the State Enterprise "Ukrainian Institute of Intellectual Property" (Ukrpatent), which is an institute of the state system of legal protection of intellectual property in Ukraine, national applicants filed 2,097 applications for inventions in 2019 (over 54\% of the total). Most applications came from applicants from Kyiv city (34.5\%), Kharkiv (16.5\%), Dnipro (9.2\%), Odesa (6.9\%), Lviv (4.5\%), Donetsk (3.5\%), Kiev (3.0\%) and Vinnytsia (2.4\%) areas, from the Mykolaiyv region - only 24 applications $(1.1 \%)$, the smallest number of applications, on $4(0.2 \%)$ - were received from Volyn and Chernivtsi regions (Ukrpatent, 2019).

In 2019 in the Mykolaiv region from the total number of subjects of management - 56309 units, only 7 belonged to a category of big enterprises, and $78 \%$ are subjects of small business which are capable to react quite dynamically and flexibly to changes both in consumer demand, and on new perspectives that open up in the implementation of research results. Under the crisis conditions associated with the threat of COVID-19, a significant advantage of small innovative enterprises is their ability to innovate, which at the first stage does not require significant investment and attract a significant amount of labor and material resources. It is especially important to create new jobs for professionals who are able to work in search of new solutions, and, above all, it may be young scientists.

Thousands of young professionals in the field of agriculture, the vast majority of whom will look for work in the city,annually graduate from higher education institutions. After conducting a survey among students of Mykolayiv National Agrarian University, we found that about $77 \%$ of respondents express a desire to live in the city and work in the areas

Table 1

Training of scientific personnel of the highest qualification in the Mykolaiyv area

\begin{tabular}{|c|c|c|c|c|c|c|}
\hline \multirow{2}{*}{ Indicators } & \multicolumn{4}{|c|}{ Years } \\
\cline { 2 - 7 } & \multicolumn{2}{|c|}{2016} & \multicolumn{2}{|c|}{2017} & \multicolumn{2}{|c|}{2018} \\
\cline { 2 - 7 } & units & persons & units & persons & units & persons \\
\hline Postgraduate studies & 5 & 205 & 5 & 174 & 5 & 4 \\
\hline Doctoral studies & 4 & 25 & 4 & 21 & 13 \\
\hline
\end{tabular}




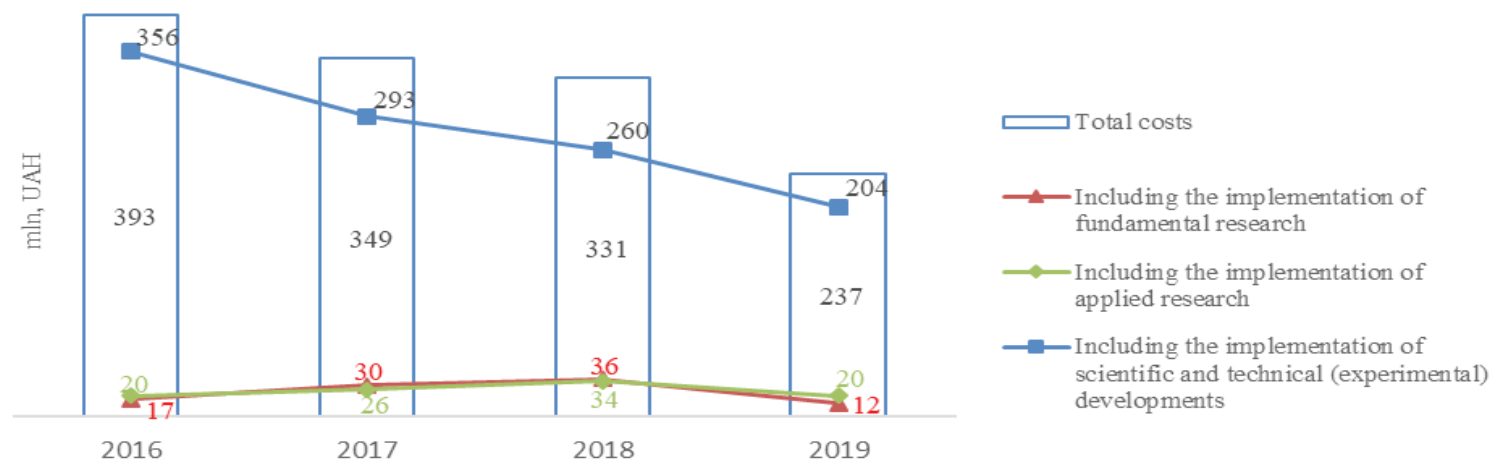

Figure 1. The cost of research and development by types of work in the Mykolaiv region, (thousand UAH) (Main department of statistics in the Mykolaiyv area, 2020).

not related to agriculture. Such answers quite clearly reflect the attitude of young people to the village, because the difference in living standards between the village and the city is huge, and among the main priorities that determine their choice, students identify economic points. In addition, part of the students talk about the lack of an adequate social environment. Such answers also suggest that without global change in the nearest future we shall not expect a large flow of graduates who will go to work in rural communities, which will worsen the already catastrophic situation in the Ukrainian countryside.

Today, there is a clear group of students (about $20 \%$ ) who want to obtain a modern higher education and after graduation work in rural communities as entrepreneurs. Therefore, the priority of regional policy should be the preservation of labor resources of rural areas, their human resources, and in light of current trends it is urgent not only to retain specialists but also to attract a significant number of new ones.

Using stochastic modeling to predict the behavior of socio-economic systems, calculations were performed to determine the most probable directions of development of the current conditions, in terms of the advantages in choosing the field of professional activity. The set of all possible professions $\Omega$ was conditionally divided into subsets of $A_{i}$, which are called occupational classes. Despite the fact that any probabilistic model describes the real process less accurately than the deterministic one, and is not able to predict changes in its parameters, this model allows to predict the expected average values of the required parameters quite satisfactorily from a practical point of view. It is also taken into account that a wide range of real processes are probabilistic in their internal structure, so that they cannot be adequately described using deterministic models. We used Markov chains, which are used as a mathematical apparatus of research in many fields, such as economics, ecology and sociology.
We have a system $\mathbf{S}$, which at any given time can be in one of $\mathbf{N}$ incompatible probable states:

$$
\omega_{1}, \omega_{2}, \ldots, \omega_{i}, \ldots, \omega_{N}
$$

and can change these states at different points in time, then for the Markov chain the conditional probability of the system to go to any possible state $\omega_{i}$ depends only on the state in which the system was at the previous time and does not depend on the states in which the system was in earlier moments of time. The general probabilistic picture of all possible transitions of system from one state to any other is set by a matrix

$$
\begin{aligned}
& \begin{array}{llllll}
\omega_{1} & \omega_{2} & \ldots & \omega_{j} & \ldots & \omega_{N}
\end{array} \\
& \omega_{1}\left[\begin{array}{llllll}
P_{11} & P_{12} & \ldots & P_{1 j} & \ldots & P_{1 N} \\
P_{21} & P_{22} & \ldots & P_{2 j} & \ldots & P_{2 N}
\end{array}\right. \\
& \pi=\begin{array}{c|cccccc}
\ldots & \ldots & \ldots & \ldots & \ldots & \ldots & \ldots \\
\omega_{i} & P_{i 1} & P_{i 2} & \ldots & P_{i j} & \ldots & P_{i N}
\end{array} \\
& \omega_{N}\left[\begin{array}{cccccc}
i 1 & P_{i 2} & \ldots & P_{i j} & \ldots & P_{i N} \\
\ldots & \ldots & \ldots & \ldots & \ldots & \ldots \\
P_{N 1} & P_{N 2} & \ldots & P_{N j} & \ldots & P_{N N}
\end{array}\right]
\end{aligned}
$$

if the condition is met

$$
\sum_{j=1}^{N} P_{i j}=1 \quad i=\overline{1, N} .
$$

Where $\boldsymbol{P}_{i j}$ - the probability of transition of the system from the state $\omega_{i}$ to the state $\omega_{j}$.

Matrix (2) is a one-step transition matrix. If there is a number $\boldsymbol{k}$ at which from any state of the chain it is possible to move to any other in $\boldsymbol{k}$ steps, then such a chain is regular.

For any probability vector $\vec{a}$ vector $\vec{a}^{\prime} \pi^{k}$ will go to the vector $\vec{W}$ with $k \rightarrow \infty$, that is 
$\lim _{k \rightarrow \infty} \vec{a}^{\prime} \pi^{k}=\vec{W}$.

$\vec{W}$ - a vector that has the following property

$$
\vec{W}^{\prime} \pi=\vec{W}^{\prime} .
$$

Condition (4) should be interpreted as follows regardless of the initial state of the vector $\vec{a}$ of the system for regular Markov chains

$$
\vec{a} \pi^{k} \underset{k \rightarrow \infty}{\longrightarrow} \vec{W} \text {. }
$$

Vector $\vec{W}$ is a vector of stationary (final) probabilities, the components of which satisfy the condition

$$
\sum_{i=1}^{N} W_{i}=1 .
$$

During the research the model of mobility of professions under change of generations on the basis of regular Markov chains for the Mykolaiv region was constructed, solved and analyzed. The input data for the model were statistical data on the structure and population in terms of areas of activity in the Mykolaiv region and Mykolaiv city for 10 years.

The choice of specific individuals for further professional activity in the intellectual or physical sphere, or in the field of agricultural production, in rural areas, is described by a matrix of regular Markov chains. The elements of the matrix inform about the average share of young people in the future to choose a profession.

Based on the results of statistical data processing, a matrix of one-step transition is constructed, which describes the general probabilistic picture of all possible transitions of the system from one state to any other, which has the form (2).

The vector of stationary (final) probabilities of states of the system $\mathrm{W}$ is defined as

$$
W=\lim _{n \rightarrow \infty} \pi^{k}
$$

$\mathrm{n}$ - the number of system states, $\mathrm{k}$ - number of forecast steps.

We have eight $(\boldsymbol{N}=\boldsymbol{8})$ system states:

- areas of activity which are typical for rural areas $-\omega_{1}-$ low-skilled manual labor that does not require special education, $\omega_{2}$ - work that requires special secondary education (mechanics, etc.), $\omega_{3}$ skilled work that requires higher education (technologists, veterinarians, agronomists, accountants, economists, administration, etc.), $\omega_{4}-$ scientific activity in agriculture;

- areas of activity which are typical for the city $-\omega_{5}-$ low-skilled manual labor that does not require special education, $\omega_{6}-$ work that requires special education, $\omega_{7}$-intellectual work that requires higher education, $\omega_{s}$ - research activities.

The largest share of the population is likely to be focused on areas of activity related to intellectual work that requires higher education. As the opportunity to realize such advantages in rural areas is extremely limited, while maintaining modern conditions, the tendency to reduce the human potential of rural areas will increase. Therefore, it is necessary to create and develop innovative activities in rural areas, in our opinion, this will contribute to the strengthening of post-industrial society in Ukraine, because it is characterized by active use of "Internet", allows you

Initial matrix

Table 2

\begin{tabular}{|c|c|c|c|c|c|c|c|c|}
\hline & $\omega_{1}$ & $\omega_{2}$ & $\omega_{3}$ & $\omega_{4}$ & $\omega_{5}$ & $\omega_{6}$ & $\omega_{7}$ & $\omega_{8}$ \\
\hline$\omega_{1}$ & 0.294 & 0.209 & 0.121 & 0.001 & 0.135 & 0.126 & 0.113 & 0.001 \\
\hline$\omega_{2}$ & 0.023 & 0.311 & 0.219 & 0.005 & 0.089 & 0.121 & 0.198 & 0.034 \\
\hline$\omega_{3}$ & 0.013 & 0.104 & 0.381 & 0.009 & 0.140 & 0.029 & 0.256 & 0.068 \\
\hline$\omega_{4}$ & 0.001 & 0.012 & 0.108 & 0.424 & 0.001 & 0.048 & 0.231 & 0.175 \\
\hline$\omega_{5}$ & 0.087 & 0.069 & 0.073 & 0.001 & 0.452 & 0.112 & 0.178 & 0.028 \\
\hline$\omega_{6}$ & 0.000 & 0.001 & 0.098 & 0.002 & 0.085 & 0.331 & 0.388 & 0.095 \\
\hline$\omega_{7}$ & 0.000 & 0.000 & 0.029 & 0.006 & 0.096 & 0.141 & 0.525 & 0.203 \\
\hline$\omega_{8}$ & 0.000 & 0.000 & 0.009 & 0.039 & 0.015 & 0.211 & 0.453 & 0.273 \\
\hline
\end{tabular}

Vector stationary probabilities

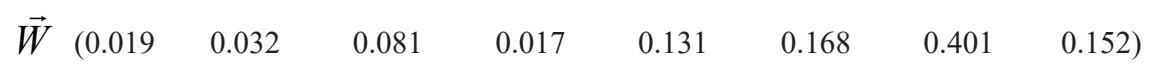


to work physically away from work. A sufficiently high level of knowledge of such people, as well as members of their families can be an additional factor in the development of the territory. Examples of such an approach we are already seeing in rural areas, which are located near regional centers or large cities. Low levels of infrastructure are also problematic issues in the practice of rural decision-making: poor roads, insufficient transport services, low levels of education and health care, that is why these areas should be considered prior to others for public policy. Initial matrix, Table 2.

According to the American sociologist and economist R. Florida, 'Natural resources and even large corporations are no longer drivers of economic progress, but the ability of cities to unite and concentrate talented people, create opportunities for them to combine and redistribute ideas and efforts, significantly enhances our innovation and productivity' (Cooke, 2003).

Therefore, according to the experience of the most competitive regions of the world, it is important for Ukraine to form and develop entrepreneurial regional innovation systems, which feature mobility and the ability to respond quickly and adequately to changing external operating conditions. In such systems, new knowledge is transferred between research centers and business structures through both formal and informal channels by involving scientists in the implementation of innovative projects funded by venture capital (Florida, 2017).

According to the modern tendencies in the Mykolaiv region, implementation of the project Innovation cluster "Regional innovative HUB" began. The Mykolaiv region became the winner of the competitive selection of grant projects at the expense of EU. RInnoHUB focuses its efforts on the implementation of the following chain "science, knowledge, experience - idea - project - experimental design - investor attraction - production - sales income - taxes". As a result of such implementation, the number of innovative enterprises is expected to grow by $15 \%$ every year. Innovation cluster
"RInnoHUB" offers: knowledge in various areas of business; business coaches and mentors with extensive experience in implementing projects of varying complexity; business consultations, startup ecosystems; convenient coworking; a laboratory where it is possible to create any prototype of a future bestseller; comprehensive support of the startup at Ukrainian and international competitions; ideas generation courses.

The work of the experimental group "Creative Laboratory" has begun. So, the innovation potential of the region is being developed, and the culture of training networks for entrepreneurs and institutions that generate and use knowledge is spreading, which strengthens the prospects for generating new innovative projects.

\section{Conclusions}

Strengthening the innovation potential of the rural areas, through the optimal use of available resources and competencies are of particular importance in conditions of fierce competition. Dynamization of innovation activity is today one of the priorities of regional development.

According to the research the largest share of the population is likely to be focused on areas of activity related to intellectual work that requires higher education and currently only a small part of the young specialists want to connect their life with the rural areas and develop there own businesses there. However, even this part of the youth has not enough possibilities and enough support to realise their ideas within the rural areas of Ukraine.

The current stage of development for the regions of Ukraine should lie in the field of a transformational transition to the model of innovative economy. This goal requires strengthening and effective implementation of the innovation potential, based on the formation of effective regional innovation systems, namely: the presence of a developed mechanism of technology transfer, effective innovation infrastructure, institutional structure, and the establishment of informal partnerships.

\section{References}

Ansoff, H.I. (1957). Strategies for Diversification, Harvard Business Review, 35(5): 113-124.

Cooke, P. (2003). "Integrating Global Knowledge Flows for Generative Growth in Scotland: Life Sciences as a Knowledge Economy Exemplar" in Inward Investment, Entrepreneurship and Knowledge Flows in Scotland - International Comparisons, Paris: OECD.

Emerging Markets Queries in Finance and Business the Relationship between Entrepreneurship, Innovation and Sustainable Development. Research on European Union Countries. Mihaela Kardosa, a 1, 540 080, Romania Retrieved February 21, 2021, from https://www.sciencedirect.com/science/article/pii/ S2212567112002699.

Florida, R. (2017). The New Urban Crisis: How Our Cities Are Increasing Inequality, Deepening Segregation, and Failing the Middle Class-and What We Can Do About It. Basic Books 
Galen, M. (2019). “Industrial Innovation, Labour Productivity, Sales and Employment”, International Journal of the Economics of Business, Retrieved February 21, 2021, from https://www.tandfonline.com/doi/full/1 $0.1080 / 13571516.2019 .1695448$.

Global Innovation Index 2020 (2020). Who Will Finance Innovation? Retrieved February 21, 2021, from https:// www.wipo.int/edocs/pubdocs/en/wipo_pub_gii_2020.pdf.

Global Innovation Index 2020 Ukraine (2020). Retrieved February 21, 2021, from https://www.wipo.int/edocs/ pubdocs/en/wipo_pub_gii_2020/ua.pdf.

Innovation for sustainable rural development (2017). CELAC, Retrieved February 21, 2021, from http://www. fao.org/3/i7769en/I7769EN.pdf.

Main department of statistics in the Mykolaiyv area (2020). Економічна статистика / Наука, технології та інновачіï (Economic statistics / Science, technology and innovation). Retrieved February 21, 2021, from http://www.mk.ukrstat.gov.ua/. (in Ukrainian).

Porter, M.E. (1996). What is Strategy, Harvard Business Reviews, 74(6): 61-78.

Porter, M.E. (2008). The Five Competitive Forces that Shape Strategy, Harvard Business Reviews, 86(1): 7893.

Schumpeter, J.A. (1939). Business Cycles: A Theoretical, Historical and Statistical Analysis of the Capitalist Process, McGraw-Hill, New York, USA

State Enterprise "Ukrainian Intellectual Property Institute” (2019). Annual Report Retrieved February 21, 2021, from https://ukrpatent.org/uk/articles/rzvit.

Thompson, A.A., \& Strickland, Jr.A.J. (2003). Strategic Management Concepts and Cases $13^{\text {th }}$ ed New York McGraw-Hill MI Irwin.

Verkhovna Rada of Ukraine (2020a). Стратегія розвитку сфериінноваџійної діяльності на період до 2030 року (Strategy for the development of innovation for the period up to 2030). Retrieved February 21, 2021, from https://zakon.rada.gov.ua/laws/show/526-2019-\%D1\%80\#n12. (in Ukrainian).

Verkhovna Rada of Ukraine (2020b). Державна стратегія регіонального розвитку на $2021-2027$ роки затверджено постановою Кабінету Міністрів Украӥни від 5 серпня 2020 р. № 695 (The state strategy of regional development for 2021-2027 was approved by there solution the Cabinet of Ministers of Ukraine of August 5, 2020 № 695). Retrieved February 21, 2021, from https://zakon.rada.gov.ua/laws/show/6952020-\%D0\%BF\#Text. (in Ukrainian). 